Journal of Applied Pharmaceutical Science Vol. 6 (07), pp. 053-060, July, 2016

Available online at http://www.japsonline.com

DOI: 10.7324/JAPS.2016.60708

ISSN 2231-3354 (cc) BY-NC-SA

\title{
Purification and characterization of a novel thermo stable L- methioninase from Streptomyces sp. DMMMH4 and its evaluation for anticancer activity
}

\author{
Mohsen Helmy Selim ${ }^{1}$, Husein Hosny Elshikh ${ }^{2}$, Moataza Mahmoud Saad ${ }^{1}$, Elsayed Eliwa Mostafa ${ }^{1}$, Mohamed \\ Abdelraof Mahmoud ${ }^{1 *}$ \\ ${ }^{1}$ Microbial Chemistry Department, National Research Center (NRC), Giza, Egypt. ${ }^{2}$ Botany and Microbiology Department, Faculty of Science (Boys), Al- \\ Azhar University, Cairo, Egypt.
}

\begin{tabular}{|c|c|}
\hline ARTICLE INFO & ABSTRACT \\
\hline Article history: & \multirow{9}{*}{$\begin{array}{l}\text { L-methioninase has been purified } 2.55 \text {-fold from the crude extract of Streptomyces sp. DMMMH4. The } \\
\text { purification procedure was carried out by heat treatment and gel filtration on Sephadex G-200 column } \\
\text { chromatography. SDS-PAGE electrophoresis showed a migrating protein band molecular mass of } 47 \mathrm{kDa} \text {. The } \\
\text { kinetic properties determined for the purified enzyme displayed optimum activity at } 70^{\circ} \mathrm{C} \text { and thermal stability } \\
\text { were } 70^{\circ} \mathrm{C} \text { for } 30 \text { min. The enzyme showed maximum activity at pH } 6 \text { using acetate buffer } 0.05 \mathrm{M} \text { and was wh } \\
\text { relatively stable across a broad range of } \mathrm{pH} \text { values }(5.5-8 \mathrm{pH}) \text {. The enzyme strongly inhibited by } \mathrm{Cr}^{+2}, \mathrm{Fe}^{+2} \text {, } \\
\mathrm{Ni}^{+2}, \mathrm{Cd}^{+2}, \mathrm{PMSF}, \beta \text {-mercaptoethanol and SDS while } \mathrm{Hg}^{+2}, \mathrm{Cu}^{+2} \text { and iodoacetate completely inhibited the } \\
\text { enzyme activity at a final concentration of } 10 \mathrm{mM} \text {. The purified enzyme exhibited a Km of } 0.7,0.15 \text { and } 0.25 \\
\text { mM for L-methionine, DL-ethionine and L-cystine respectively. Cytotoxicity test demonstrate that enzyme was } \\
\text { active against liver HepG2, breast MCF-7, lung A549, prostate PC } 3 \text { and colon HCT116 cancer cell lines and has } \\
\text { negligible toxicity toward a normal melanocyte cell line HFB4. }\end{array}$} \\
\hline Received on: $25 / 02 / 2016$ & \\
\hline Revised on: $21 / 04 / 2016$ & \\
\hline Accepted on: 17/05/2016 & \\
\hline Available online: $28 / 07 / 2016$ & \\
\hline Key words: & \\
\hline L-methioninase, & \\
\hline Streptomyces sp DMMMH4, & \\
\hline $\begin{array}{l}\text { Purification, Thermo stable, } \\
\text { anticancer. }\end{array}$ & \\
\hline
\end{tabular}

\section{INTRODUCTION}

L-Methioninase (EC4.4.1.11; MGL), is a pyridoxal-5'phosphate- dependent enzyme, catalyzes the $\gamma$-elimination of Lmethionine to generate $\alpha$-ketobutyrate, methanethiol, and ammonia as well as the $\alpha, \beta$-replacement and $\beta$-elimination of $S$ substituted L-cysteines (Tanaka et al., 1983). A major potential therapeutic application of enzymes is in the treatment of cancer. Therefore, much attention has been paid to L-methioninase which have demonstrated antitumor efficacy in vitro as well as in vivo (Kahraman et al., 2011; Tan et al., 1998). L-methioninase is one of few microbial enzymes with high therapeutic value since it was reported as a potent anticancer agent against various types of tumor cell lines Breast, Lung, Colon, Kidney and Glioblastoma (Kokkinakis et al., 2001; Tan et al., 1998). Many human cancer cell lines and primary tumors have an absolute

* Corresponding Author

Email:abdelraof87@gmail.com requirement for L-methionine as an essential amino acid, to survive and proliferate (Anderson, 1998). On the other hand, normal cells are methionine independent as they have active methionine synthase. Thus, they can grow on a medium supplemented with homocysteine, vitamin B12 and folic acid instead of methionine. The absence of methionine synthase in many tumors, in contrary to the normal cells, partially explains the inability of tumor cells to grow on homocystein (Kahraman et al., 2011 and Cellarier et al., 2003). Consequently, methionine is the main tumor specific target for therapeutic techniques. Therefore, therapeutic exploitation of $\mathrm{L}$-methioninase to deplete plasma methionine seems to be a promising strategy (Sharma et al., 2014; Sundar and Nellaiah, 2013; Pinnamaneni et al., 2012; Yoshioka et al., 1998). L-methioninase was extensively characterized from various bacterial species especially Pseudomonas. Purification of L-methioninase from Pseudomonas ovalis was carried out by (Tanaka et al., 1976). They reported that, the purified enzyme had a molecular weight of $43 \mathrm{KDa}$. 
A similar enzyme from a different clone of Pseudomonas putida was isolated and purified by (Ito et al., 1976). The purified enzyme from Pseudomonas putida ICR 3460 was published by (Nakayama et al., 1984) has a molecular weight 43KDa. Furthermore, pure L-methioninase was also obtained from other species of bacteria such as Colstridium sporogens (Kreis and Hession, 1973), Brevibacterium linens (Pinnamaneni et al., 2012). On the other hand, a few studies on the purification and characterization of L-methioninase from fungi such as Aspirgillus flvips reported by (El-Sayed, 2011), the purified enzyme had a molecular mass 47 KDa. In addition, Purification and characterization of this enzyme from the yeast was carried out by (Selim et al., 2015a). To our knowledge, no investigation has yet been performed on purification of this enzyme from Streptomyces species. Although, the only reported on the production of this enzyme by Streptomyces Sp was published through us (Selim et al., 2015b). In the present work, we purified and characterized of a new L-methioninase from Streptomyces sp. DMMMH4 and were to evaluate in-vitro anticancer activity.

\section{MATERIAL AND METHODS}

\section{Materials}

\section{Chemicals and reagents}

The source of chemicals and reagents used in this study were as follows: L-methionine from (Merk, Germany). Methanethiol used as sodium methanethiolate; Pyridoxal-5phosphate (PLP); 5,5-Dithiobis-2-nitrobenzoicacid (DTNB); Commassi Brilliant Blue G-250 and bovine serum albumin (BSA) were obtained from Sigma-Aldrich (Sigma, St. Louis, USA). Sephadex G-200 and DEAE-cellulose were purchased from Pharmica Biotechnology (Sweden). Cancer and normal cells were obtained from the American Type Culture Collection (ATCC, Rockville, MD, USA). All other chemicals were of the highest analytical grade.

\section{Methods}

Streptomyces strain and production conditions:

Streptomyces sp. DMMMH4 was deposited in the DDBJ/EMBL/GenBank nucleotide sequence databases with accession number: LC021308. This strain was previously isolated from Egyptian soil and chosen as a most potent L-methioninase producer (Selim et al., 2015b). The enzyme production medium used is a modified starch medium. It's contained $(\mathrm{g} / \mathrm{L})$ : Starch, 20; L-methionine, $3 ; \mathrm{MgCl}_{2}$ anhydrous, $1.5 ; \mathrm{CaCO}_{3}, 3$ and yeast extract. In addition, growth medium was adjusted to 7 using potassium phosphate buffer $0.075 \mathrm{M}$. After four days of growth with shaking (150 rbm, New Brunswick, USA) cells were harvested by centrifugation (5500 rpm, Herml, Germany). The clear supernatant was used as a crude enzyme.

\section{Protein determination}

Protein concentration was determined according to the method of (Bradford, 1976) and its determination in the purified fractions using method of (Schleif and Wensink, 1981) with bovine serum albumin as standard.

\section{L-methioninase assay}

L-Methioninase activity was determined by the method of (Arfi et al., 2003; Laakso et al., 1976) using L-methionine as a substrate. Methanethiol (MTL) produced from substrate reacted with 5,5 dithio-bis-2-nitrobenzoicacid added (DTNB) to form thionitrobenzoic acid was detected spectrophotometrically at 412 $\mathrm{nm}$ (Agilent UV/Vis. Cary-100). The assay mixture contained $20 \mathrm{mM}$ of L-methionine in $0.1 \mathrm{M}$ potassium phosphate buffer $\mathrm{pH}$ 7.0, 0.02mM PLP, $0.25 \mathrm{mM}$ DTNB and the supernatant in a final volume of $1 \mathrm{ml}$. One unit (U) of L-methioninase was expressed as the amount of enzyme that releases $1 \mu$ mole of methanethiol per minute under optimal assay conditions.

In addition, Deaminating activity was carried out by measuring on releasing ammonia from L-methionine according to (Spinnler et al., 2001) using Nessler's reagent. One unit (U) of enzyme activity was expressed as the amount of enzyme that releases one $\mu \mathrm{mol}$ of ammonia per minute under optimal assay conditions.

\section{L-methioninase Purification}

The clear supernatant obtained was used as the crude enzyme preparation for the subsequent steps. According to the method of (Selim et al., 2015a), the enzyme was partially purified by heating the supernatant at different temperatures $\left(60-70^{\circ} \mathrm{C}\right)$ for different times (10-25min.) intervals. After cooling on ice the denatured proteins were removed using cooling centrifuge (Sigma, Germany at 5500 RPM) for $15 \mathrm{~min}$. The active fraction was dialyzed overnight against the same volume of $0.05 \mathrm{M}$ potassium phosphate buffer, $\mathrm{pH} .7$ amended with $0.02 \mathrm{mM}$ PLP.

The dialyzed supernatant was applied to a $(2.5 \times 50 \mathrm{~cm})$ column of Sephadex G-200 pre-equilibrated with $0.05 \mathrm{M}$ potassium phosphate buffer $\mathrm{pH} 7$ containing $0.02 \mathrm{mM}$ PLP. The enzyme fractions were eluted with the same buffer at a flow rate $1 \mathrm{ml} / 5 \mathrm{~min}$. Eliot (5 $\mathrm{ml}$ fractions) was collected separately for the measurement of enzyme activity and protein content. The active fractions were combined and the solution was concentrated and collected prior to confirm the purity of enzyme and determination of molecular mass by (SDS-PAGE).

\section{Determination of purity and molecular mass of L-methioninase}

The homogeneity of purified L-methioninase was checked using dissociating polyacrylamide gel electrophoresis (SDS-PAGE) according to a protocol proposed by (Lammeali, 1970) with standard marker proteins.

\section{Statistical analysis}

Results are expressed as the mean \pm S.D, calculated using excel 2010. 
Effect of pH on the enzyme activity and stability

The optimum $\mathrm{pH}$ for pure enzyme activity was determined using $0.05 \mathrm{M}$ of different buffers (i.e.) acetate $(\mathrm{pH} 4.0$ 6.0); potassium phosphate $(\mathrm{pH}$ 6.5- 8.0) and Glycine- $\mathrm{NaOH}$ (8.510). After incubation with different buffers, each reaction enzymatic activity was estimated. The $\mathrm{pH}$ stability of the enzyme was determined by preincubating the enzyme solution at different $\mathrm{pH}$ values ranging from 4.0 to 10 for $18 \mathrm{~h}$ at $4^{\circ} \mathrm{C}$ and at room temperature $33^{\circ} \mathrm{C}$. At the end of preincubation time the $\mathrm{pH}$ value of enzyme solution was readjusted to $\mathrm{pH} 7$ i.e. (optimum $\mathrm{pH}$ used in standard assay method) and then residual enzyme activity was assayed by the standard method.

\section{Effect of temperature on the enzyme activity and stability}

The effect of reaction temperature on pure enzyme activity was determined by incubating the reaction mixture at different temperatures ranging $\left(30-90^{\circ} \mathrm{C}\right)$. On the other hand, the thermal stability of the purified enzyme was determined by preincubating the enzyme solution at various temperatures (30$90^{\circ} \mathrm{C}$ ) for different times (0-100 min) in the absence of substrate. Followed by aliquots was removed, cooled of enzyme solution and the residual activity was measured by the standard assay method as previously mentioned.

\section{Effect of some metal ions and chemical reagents on the enzyme activity}

Metal ions with chloride salt and some chemical reagents tested for their effects on pure enzyme activity by incubating enzyme solution with 1 and $10 \mathrm{mM}$ final concentrations for $4 \mathrm{~h}$ before adding the substrate. After preincubation time, enzymatic activity was determined under optimal assay conditions.

\section{Determination of kinetic parameters}

In this experiment, the kinetic parameters such as Michalis-Menten constant $(\mathrm{Km})$ and maximum velocity (Vmax) of purified L-methioninase was determined by incubating the enzyme using different concentrations of each substrate in the range of (1$70 \mathrm{mM}$ ) under optimum assay conditions. The apparent $\mathrm{Km}$ and Vmax of purified enzyme were calculated from a LineweaverBurk plot.

\section{In-Vitro anticancer activity assay}

To determine the effect of Purified L-methioninase as anticancer activity, we tested the viability of cancer cell lines exposed to various concentrations of pure enzyme. Anticancer activity was expressed by median growth inhibitory concentration $\left(\mathrm{IC}_{50}\right)$. The antiproliferative activity of pure enzyme was evaluated against liver HepG2, breast MCF-7, lung A549, prostate PC3 and colon HCT116 cancer cell lines as well as the normal cell line (human normal melanocyte, HFB4) in comparison with doxorubicin as reference drug. The cells were grown and maintained in RPMI-1640 medium supplemented with $10 \%$ heat inactivated fetal calf serum (GIBCO), penicillin $(100 \mathrm{U} / \mathrm{ml})$ and streptomycin $(100 \mu \mathrm{g} / \mathrm{ml})$. The cells were maintained at $37^{\circ} \mathrm{C}$ in humidified atmosphere containing $5 \% \mathrm{CO}_{2}$. The cancer cell lines were suspended in medium at cells concentration of $5 \times 10^{4}$ cell/well in Corning® 96-well tissue culture plates grown in a 25 $\mathrm{cm}^{2}$ flask in $5 \mathrm{ml}$ of culture medium, and then incubated for $24 \mathrm{~h}$. The tested enzyme was then added into 96 well plates (six replicates) to achieve eight concentrations of enzyme. Six vehicle controls with media or $0.5 \%$ DMSO were run for each 96 well plate as a control. After incubation for $24 \mathrm{~h}$, the numbers of viable cells were determined by the MTT test (Mosmann, 1983).

\section{RESULTS AND DISCUSSION}

\section{Purification of L-methioninase}

Purification of L-methioninase to homogeneity was accomplished in two successive steps Table (1). Nine eighty percent of L-methioninase activity was obtained from heat treatment at $70^{\circ} \mathrm{C}$ for $10 \mathrm{~min}$. Separation of enzyme from other proteins by gel filtration using Sephadex G-200 Fig. (1) resulted in a homogenous enzyme which was purified 2.55 fold with an activity yield of 49.1 .

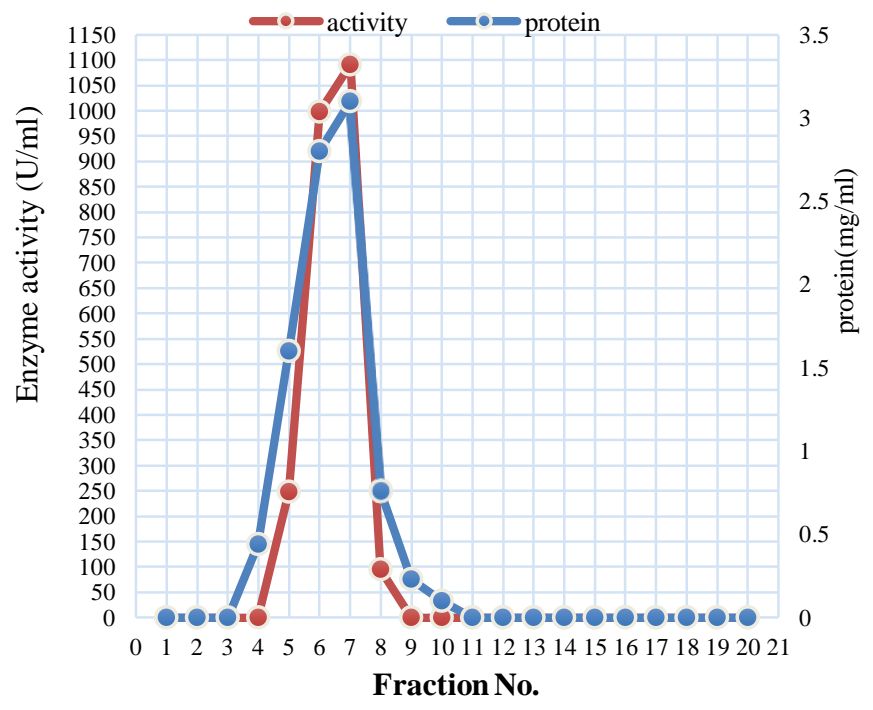

Fig. 1: Purification of L-methioninase using sephadex G-200.

On the other hand, when the gel was electrophoresd under denaturing conditions, a single band with an approximate molecular mass of $47 \mathrm{KDa}$ was noted Fig. (2).

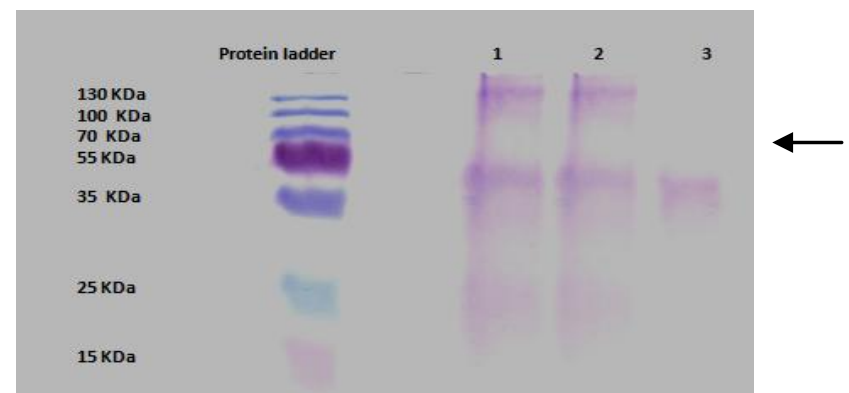

Fig. 2: Electrophoresis of Streptomyces sp. DMMMH4 L-methioninase under the denaturing conditions of SDS-PAGE (12\% acryl amide gel). Protein ladder: Molecular mass marker; gel lane 1: crude enzyme; gel lane 2: Heat treatment Gel lane 3: Sephadex G-200 column. 
This enzyme has been purified from various sources but with several steps, L-methioninase from Brevibacterium linens was purified in five purification steps, including ammonium sulfate precipitation followed by several chromatographic procedures. Purified L-methioninase obtained from Citrobacter freundii by heat treatment at $60^{\circ} \mathrm{C}$ followed by separation on DEAE-cellulose column and Sephacryl S-200HR column (Munkhov et al., 2005). Partial purification of this enzyme by heat treatment is consistent with published literature reported for purification from Pseudomonas putida (Tan et al., 1998; Hori et al., 1996). In contrast, Streptomyces sp. DMMMH4 Lmethioninase was purified using only two steps compared to other microbial sources. Accordingly, our results of molecular mass of the enzyme are in agreement with reported by L-methioninases purified from different sources, the molecular mass of Lmethioninase purified from Citrobacter freundii (Munkhov et al., 2005) was found to range from 43.0 to $45.0 \mathrm{kDa}$ per subunit. while, the purified enzyme from Aspergillus flavipes had a molecular mass 47 kDa (El-Sayed, 2011).

\section{Effect of pH on the enzyme activity and stability:}

Results in Fig. (3) indicate that somewhat acidic and neutral $\mathrm{pH}$ values $(6-7 \mathrm{pH})$ using acetate and potassium phosphate buffers $0.05 \mathrm{M}$ were the most favorable for enzyme activity, the maximum activity of enzyme was obtained at $\mathrm{pH} 6$ when acetate buffer $0.05 \mathrm{M}$ was used (103.9\%).

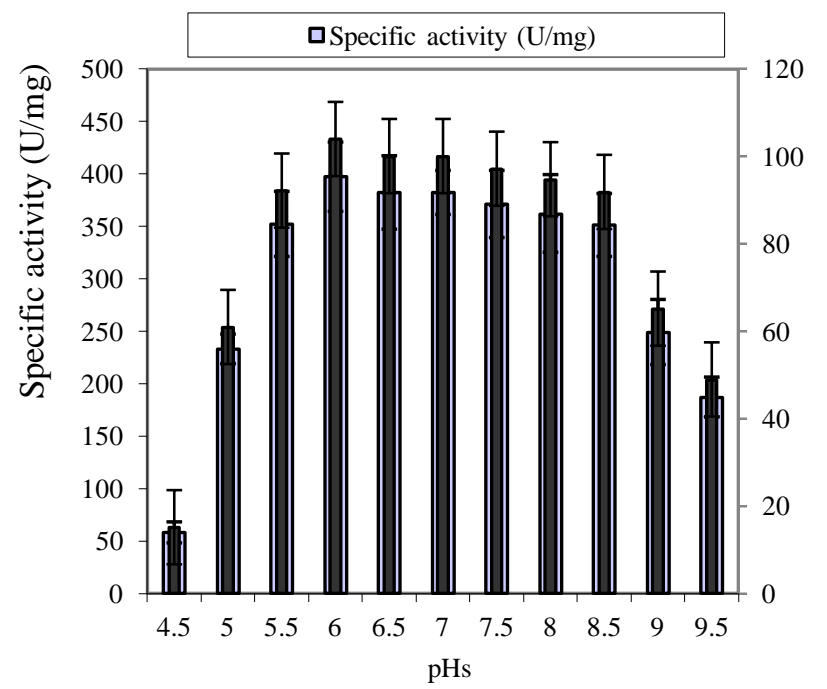

Fig. 3: Effect of $\mathrm{pH}$ on enzyme activity

In addition, when $\mathrm{pH} 6$ adjusted using acetate buffer with different molarities from $(0.025-0.20 \mathrm{M})$, the response of enzyme activity was increased with the increase of buffer molarities reaching its maximum value when $0.05 \mathrm{M}$ was applied Fig. (4).

Furthermore, the enzyme was found to be stable in the $\mathrm{pH}$ range 6-8 and was more labial in the acidic region than in the alkaline region as shown in Table (2).

The optimum $\mathrm{pHs}$ for enzyme activity will be studied by many authors, for Aspergillus flavipes neutral to slightly alkaline
$\mathrm{pH}(7-8 \mathrm{pH})$ was optima for its pure enzyme activity (El-sayed, 2011). While pH 6.5 was the most suitable for Candida tropicalis L-methioninase activity (Selim et al., 2015a). On the other hand, the alkaline range of $\mathrm{pH}$ correlated with maximum enzyme activity for bacteria, Pseudomonas putida (Nakayama et al., 1984) \& Citrobacter freundii (Mankhov et al., 2005).

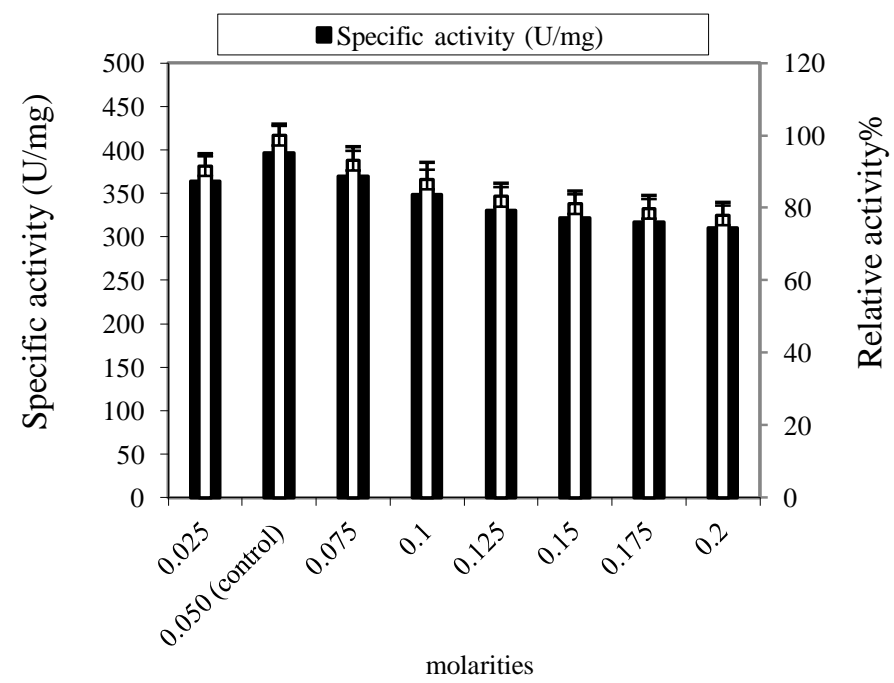

Fig. 4: Effect of different molarities on enzyme activity

Table 2: Effect of $\mathrm{pH}$ stability on the pure L-methioninase activity.

\begin{tabular}{cccccc}
\hline Buffer & pH & $\begin{array}{c}\text { Relative } \\
\text { activity \% }\end{array}$ & Buffer & pH & $\begin{array}{c}\text { Relative } \\
\text { activity \% }\end{array}$ \\
\hline A & 4 & 51.8 & $\mathrm{~B}$ & 8 & 99.4 \\
$\mathrm{~A}$ & 4.5 & 76.9 & $\mathrm{C}$ & 8.5 & 94.2 \\
$\mathrm{~A}$ & 5.0 & 89.2 & $\mathrm{C}$ & 9 & 84.8 \\
$\mathrm{~A}$ & 5.5 & 96 & $\mathrm{C}$ & 9.5 & 77.6 \\
$\mathrm{~A}$ & 6 & 100 & $\mathrm{C}$ & 10 & 72.7 \\
$\mathrm{~B}$ & 6.5 & 100 & & & \\
$\mathrm{~B}($ control) & 7 & 100 & & & \\
B & 7.5 & 100 & & & \\
\hline Where: A=Acetate Buffer, B= K. Phosphate Buffer, C= Glycine. NaOH Buffer.
\end{tabular}

On the other hand, the stability of the enzyme at different pHs higher than $\mathrm{pH} 8.5$ and lower than $\mathrm{pH} 5$ resulted in a decrease of enzyme activity, (El-sayed, 2011) suggesting that the lower stability of the enzyme at a higher and lower pHs may be attributed to the dissociation of pyridoxal-5-phosphate or unfolding of the enzyme active site. In addition, our data in agreement with (El-sayed, 2011) who mentioned that the isoelectric point of the enzyme was $\mathrm{pH} 4.8$ and the lower enzyme stability in acidic conditions may be due to the closeness of his enzyme to the isoelectric point. The $\mathrm{pH}$ stability of the enzyme from other sources was over range from 7 to 8 (Dias and Weimmer, 1998; Tanaka et al,. 1976).

\section{Effect of temperature on the enzyme activity and stability}

Data presented in Fig. (5) demonstrated the optimum temperature for the enzyme activity was found to be $70^{\circ} \mathrm{C}$ and it has significant activity over rang $60-75^{\circ} \mathrm{C}$. A slight decrease is obtained at higher temperatures $\left(80-90^{\circ} \mathrm{C}\right)$. 


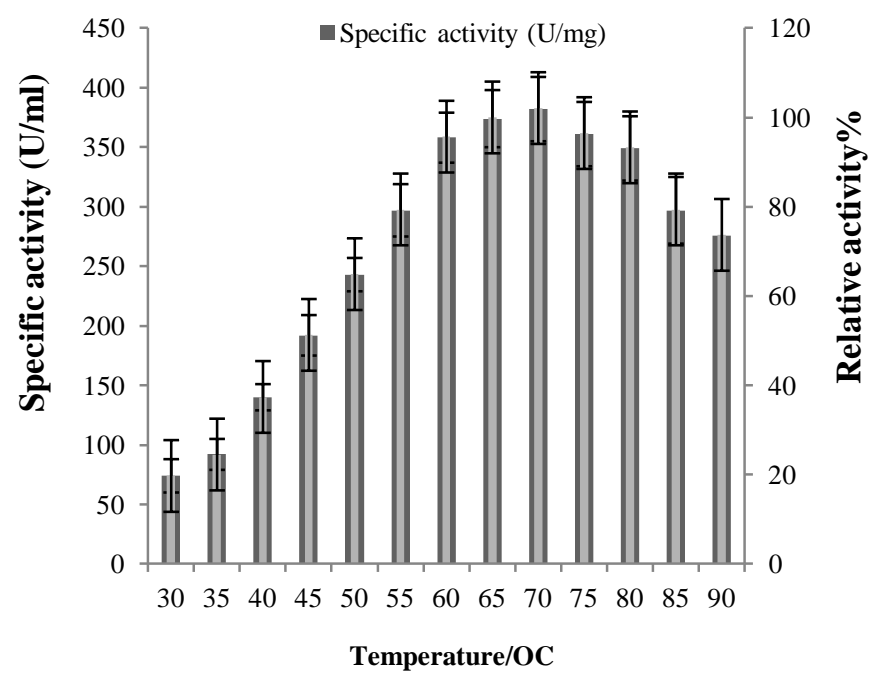

Fig. 5: Effect of temperature on enzyme activity

The progress of the enzymatic reaction with time was studying at the optimum temperature $70^{\circ} \mathrm{C}$. The rate of $\mathrm{L}$ methionine hydrolysis with time up to $10 \mathrm{~min}$. Thereafter, no more hydrolysis occurred (data not shown). On the other hand, From the results are shown in Fig. (6), it could be noticed that, the pure enzyme was more stable up to $50^{\circ} \mathrm{C}$ for $100 \mathrm{~min}$ and not loss of activity followed by a slight decrease of the enzyme stability after $1 \mathrm{hr}$ at $60^{\circ} \mathrm{C}$ was occurring. In addition, a severe inhibition of enzyme activity (15\%) was noticed when the enzyme was incubated at $90^{\circ} \mathrm{C}$ for $100 \mathrm{~min}$. In comparison with enzyme produced by other sources, our enzyme could be consider as a promising agent for its high stability (thermo stable).

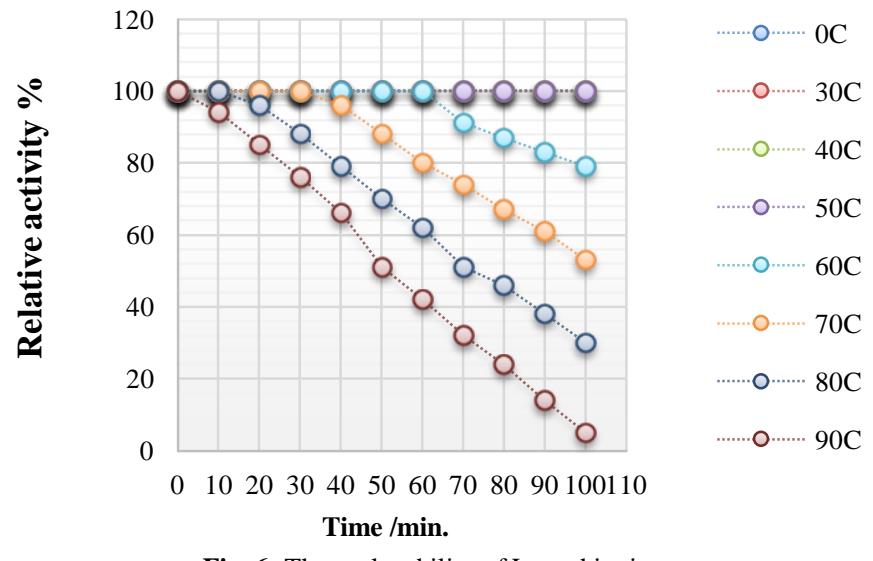

Fig. 6: Thermal stability of L-methioninase

Pseudomonas putida had optimal activity at $35^{\circ} \mathrm{C}$ for different times reported by (Nakayama et al., 1984). Similar ranges were reported for several bacteria such as Brevibacterium Linens (Pinnamaneni et al., 2012), and Citrobacter intermedius (Faleev et al., 1996). In addition, (El-sayed, 2011) reported that, the optimum temperature for L-methioninase activity obtained from Asperigillus flavipes was observed $35^{\circ} \mathrm{C}$. Moreover, maximum activity of L-methioninase from Candida trobicalis was $45^{\circ} \mathrm{C}$ and the reaction time increased up to $20 \mathrm{~min}$ (Selim et al., 2015a). Thermal stability of the enzyme from different sources was investigated by (Dais and Weimmer, 1998) they showed that L-methioninase from Brevibacterium linins had a thermal stability below $40^{\circ} \mathrm{C}$ and also (El-sayed, 2011) finding the enzyme from Aspirgillus Flavipes displayed a relative catalytic stability below a temperature of $40^{\circ} \mathrm{C}$.

\section{Substrate Specificity of Purified L-Methioninase}

The ability of enzyme to catalyze the $\gamma$-elimination of various Sulfur containing amino acids is presented in Fig. (7). These amino acids were added with equal amounts $(20 \mathrm{mM})$ separately to the reaction mixture and incubated under optimum assay conditions. Data obtained from Fig. (7) indicate relative activities of the enzyme on these substrates. L-methioninase was found to degrade DL-ethionine with $103.7 \%$ more than Lmethionine, followed by cystine and cysteine with $96.4 \%$ and $83.2 \%$ respectively. The enzyme exhibited high specificity for DLethionine then L-methionine and L-cystine.

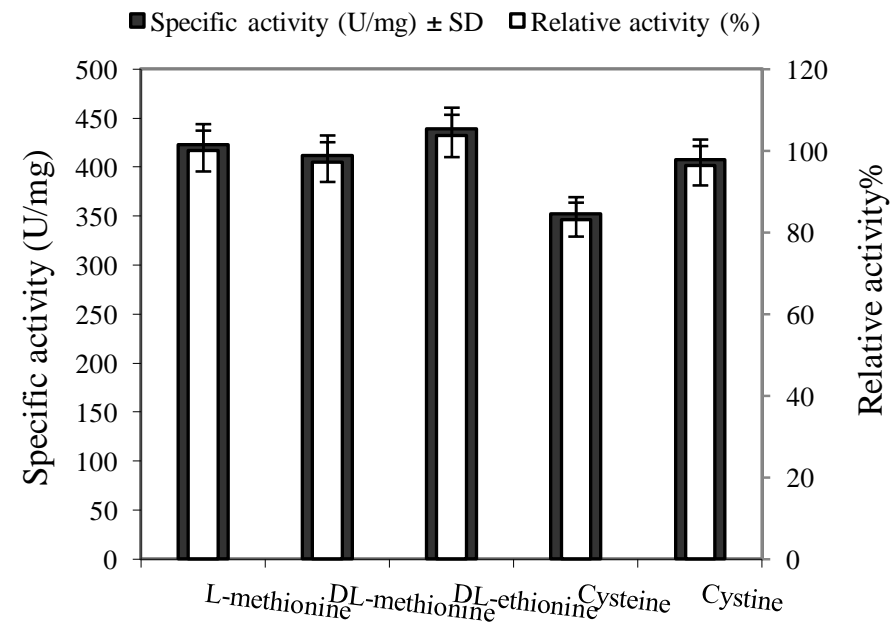

Substrates

Fig. 7: Substrate specificity of purified L-methioninase.

The relative activity of L-methioninase towards the sulfur containing amino acids may be due to the similar molecular configuration of $\alpha \& \beta$ carbons (El-sayed, 2011). (Tanaka et al., 1976) mentioned that L-methionine is the preferred substrate for L-methioninase purified from Pseudomonas putida. Furthermore, several derivatives of L-methionine and L-cysteine serve as effective substrate. Studies on the substrate specificity of Candida tropicalis L-methioninase revealed that the enzyme had a relative activity towards various sulfur containing amino acids (Selim et al., 2015a).

\section{Determination of $\mathrm{Km}$ and $V \mathrm{max}$}

L-methionine, DL-ethionine and L-cystine were serve as effective substrates thus we are calculating $\mathrm{Km}$ and Vmax for each from a Lineweaver-Burk plot. The $\mathrm{Km}$ and Vmax values was found to be $(0.7 ; 0.15 \& 0.25 \mathrm{mM})$ and $(441 ; 452 \& 504$ $\mathrm{U} / \mathrm{mg} / \mathrm{min}$.) for L-methionine, DL-ethionine and L-cystine 
respectively as shown in Table (3). The enzyme showed maximal activity at a substrate level of 40,60 and $50 \mathrm{mM}$ for L-methionine, DL-ethionine and L-cystine respectively; this indicates that the active center of the enzyme became saturated with each substrate at concentrations above 40, 60 and $50 \mathrm{mM}$. $\mathrm{Km}$ and $\mathrm{V}_{\max }$ were showing a high affinity of enzyme to its substrates exhibiting a low value of $\mathrm{Km}$ and confirmed its high therapeutic value of the enzyme. In this respect, L-methioninase from Pseudomonas putida (Esaki and Soda, 1987) was reported to exhibit a Km of $1 \mathrm{mM}$. In addition, The purified enzyme exhibited a $\mathrm{Km}$ of $0.7 \mathrm{mM}$ from Citrobacter freundii (Munkhov et al., 2005).

Table 3: Kinetics of L-methioninase for different substrates.

\begin{tabular}{lcc}
\hline Substrate & Vmax (U/mg/min.) & Km(mM) \\
\hline L-methionine & 441 & 0.7 \\
DL-ethionine & 452 & 0.15 \\
D-cystine & 504 & 0.25 \\
\hline
\end{tabular}

\section{Effect of Different Metal Ions and Inhibitors on L- methioninase Activity}

The enzyme activity in the presence of metal ions and some chemical reagents was also determined. The results presented in Table (4) demonstrated that L-methioninase activity was inhibited and loss more than $50 \%$ of its activity when preincubating with $\mathrm{Ni}, \mathrm{Cu}, \mathrm{Cr}, \mathrm{Cd}, \mathrm{SDS}$ and iodoacetate at a final concentration of $10 \mathrm{mM}$. Whereas an increase and the stimulatory effect on enzyme activity found to be occurring with $\mathrm{Mg}$ and EDTA at both concentrations $(1 \& 10 \mathrm{mM})$ by the relative enzyme activities (102\& $100.2 \%$ and $101.8 \& 100.4 \%$, respectively).

Furthermore, insensitivity of the enzyme activity to EDTA (a metallic protease inhibitor) indicated that the functioning of enzyme did not have the absolute requirement of metal ions and ensuring the non-metallic nature of this enzyme. All thiol compounds, DTT, glutathione, and $\beta$-mercabtoethanol had an inhibitory effect on enzyme activity by $68.2,88.8$ and $65 \%$, respectively while the enzyme was completely inactivated by a thiol reducing agent iodoacetate, the complete inhibition of enzyme with this agent provides evidence for the presence of $-\mathrm{SH}$ group in the active sites of enzyme. Triton X-100 had a significant slight effect on enzyme activity compared to tween $(80 ; 20)$ as reflected by the relative enzyme activities (92.7 and 100\%, respectively). While the effect of sodium dodecyl sulfate as a strong surfactant on the enzyme was remaining $40.5 \%$ of its activity at $10 \mathrm{mM}$. Additionally, enzyme was strongly inhibited by PMSF, $\beta$-mercaptoethanol, SDS, and DTT suggests the presence of a cysteine/disulfide bond for maintaining the molecular catalytic folding state of the enzyme, consistent with the results obtained by (Thong et al., 1987) and (Lockwood and Coombs, 1991). (Ferchechi et al., 1986) showed that, the enzyme activity of Brevibacterium linens was stimulated by $\mathrm{Na}^{+}$and $\mathrm{K}^{+}$and strongly inhibited by $\mathrm{Zn}^{+2}, \mathrm{Mn}^{+2}$, and $\mathrm{Cu}^{+2}$. (Dais and Weimmer, 1998) founded that iodoacetate inhibited enzyme activity at $10 \mathrm{mM}$ while metal chelating agents did not influence enzyme activity. On the other hand, enzyme purified from Aspergillus flavipes was strongly inhibited by DL-propargylglycine, hydroxylamine,
PMSF, $\beta$-mercaptoethanol, $\mathrm{Hg}^{+}, \mathrm{Cu}^{2+}$, and $\mathrm{Fe}^{2+}$ and slight inhibition by Triton X-100 (El-Sayed, 2011).

Table 4: Effect of some Metal Ions and chemical reagents.

\begin{tabular}{|c|c|c|}
\hline \multirow{3}{*}{$\begin{array}{c}\text { Metal Ions and } \\
\text { chemical reagents }\end{array}$} & \multicolumn{2}{|c|}{ Concentrations } \\
\hline & $1 \mathrm{mM}$ & $10 \mathrm{mM}$ \\
\hline & Relative activity (\%) & Relative activity (\%) \\
\hline Control & 100 & 100 \\
\hline $\mathrm{K}^{+}$ & 98.8 & 96.8 \\
\hline $\mathrm{Na}^{+}$ & 97.7 & 95.2 \\
\hline $\mathrm{Ca}^{2+}$ & 98.6 & 98.8 \\
\hline $\mathrm{Mg}^{2+}$ & 102 & 100.2 \\
\hline $\mathrm{Ba}^{+}$ & 95.9 & 66.4 \\
\hline $\mathrm{Zn}^{2+}$ & 96.5 & 77.3 \\
\hline $\mathrm{Ni}^{2+}$ & 51.4 & 35.1 \\
\hline $\mathrm{Cu}^{2+}$ & 77.3 & 2.26 \\
\hline $\mathrm{Mn}^{2+}$ & 61.8 & 55 \\
\hline $\mathrm{Hg}^{2+}$ & 11.7 & 0 \\
\hline $\mathrm{Cd}^{2+}$ & 72.7 & 15.4 \\
\hline $\mathrm{Co}^{2+}$ & 99 & 97.9 \\
\hline $\mathrm{Fe}^{2+}$ & 55.3 & 50.4 \\
\hline $\mathrm{Cr}^{2+}$ & 24.2 & 13.3 \\
\hline $\mathrm{Li}^{2+}$ & 98.8 & 92.7 \\
\hline Dithiotheritol & 87.7 & 68.2 \\
\hline Glutathione & 89.3 & 88.8 \\
\hline Mercaptoethanol & 87.9 & 65 \\
\hline Tween 80 & 100 & 100 \\
\hline Tween 20 & 100 & 97.7 \\
\hline Triton $\mathrm{x}-100$ & 97.7 & 92.7 \\
\hline SDS & 91.1 & 40.5 \\
\hline DMSO & 94.7 & 86.6 \\
\hline EDTA & 101.8 & 100.4 \\
\hline PMSF & 92.7 & 60.7 \\
\hline Iodoacetate & 39 & 0 \\
\hline
\end{tabular}

\section{In-vitro anticancer activity of L-methioninase}

The results Table (5) revealed that a good remarkable anticancer activity against cancer cells. L-methioninase was found to be potent anticancer agents had $\mathrm{IC}_{50}$ values near to the standard drug doxorubicin in various cancer cells with $\mathrm{IC}_{50}$ values $4.29 \pm 0.44 \mu \mathrm{g} / \mathrm{ml}(0.127 \mathrm{U} / \mathrm{ml})$ in case of lung A549; $7.11 \pm 0.82$ $\mu \mathrm{g} / \mathrm{ml}(0.21 \mathrm{U} / \mathrm{ml})$ in case of colon HCT116; $6.39 \pm 0.71 \mu \mathrm{g} / \mathrm{ml}$ $(0.19 \mathrm{U} / \mathrm{ml})$ in case of prostate PC $3 ; 5.71 \pm 0.64 \mu \mathrm{g} / \mathrm{ml}(0.17 \mathrm{U} / \mathrm{ml})$ in case of breast MCF-7; and $4.33 \pm 0.46 \mu \mathrm{g} / \mathrm{ml}(0.13 \mathrm{U} / \mathrm{ml})$ in case of liver HepG-2 versus the standard drug doxorubicin which had $\mathrm{IC}_{50}$ values $4.11 \pm 0.50,5.80 \pm 0.65,5.60 \pm 0.63,2.96 \pm 0.34$ and $3.97 \pm 0.45 \mu \mathrm{g} / \mathrm{ml}$ respectively, in A549, HCT116 , PC3, MCF-7 and HepG2 cells. It is clear that cancer cell lines were tested are more sensitive to L-methioninase. Additionally, the results revealed that L-methioninase has no toxicity against the growth of normal melanocytes HFB4 cells.

The strong inhibition of these cancer growth by action of L-methioninase, ensure its methionine auxotrophic identity for cancer cells. The efficiency of L-methioninase against various cell lines was reported by many authors (Tan et al., 2010; Sundar and Nellaiah, 2013 \& Kui-Ying et al., 2015). The sensitivity of cancer cell lines to L-methioninase was investigated by (Hori et al., 1996) they tested L-methioninase produced by Pseudomonas putida against various cancer cell lines and leukemia cell lines are more sensitive to L-methioninase than solid tumor cell lines. (Tan et al., 2010) showed that the rMETase was efficacy in broad series of cancer cell lines. 
Table 5: In-vitro cytotoxic activity of L-methioninaseas expressed as $\mathrm{IC}_{50}$ values on different cell lines.

\begin{tabular}{|c|c|c|c|c|c|c|}
\hline \multirow{2}{*}{ Compounds } & \multicolumn{6}{|c|}{$\mathrm{IC}_{50}(\mu \mathrm{g} / \mathrm{ml})$} \\
\hline & MCF-7 & HepG2 & A549 & HCT116 & PC3 & HFB4 \\
\hline Doxorubicin (Standard drug) & $2.96 \pm 0.34$ & $3.97 \pm 0.45$ & $4.11 \pm 0.50$ & $5.80 \pm 0.65$ & $5.60 \pm 0.63$ & $87.71 \pm 9.83$ \\
\hline $\begin{array}{l}\text { L-methioninase } \\
(\mathrm{U} / \mathrm{ml})\end{array}$ & $\begin{array}{c}5.71 \pm 0.64 \\
(0.170 \mathrm{U} / \mathrm{ml})\end{array}$ & $\begin{array}{c}4.33 \pm 0.46 \\
(0.131 \mathrm{U} / \mathrm{ml})\end{array}$ & $\begin{array}{c}4.29 \pm 0.44 \\
(0.127 \mathrm{U} / \mathrm{ml})\end{array}$ & $\begin{array}{c}7.11 \pm 0.82 \\
(0.216 \mathrm{U} / \mathrm{ml})\end{array}$ & $\begin{array}{c}6.39 \pm 0.71 \\
(0.190 \mathrm{U} / \mathrm{ml})\end{array}$ & N.A \\
\hline
\end{tabular}

They reported that $\mathrm{rMETase}$ had a mean $\mathrm{IC}_{50}$ (units $\left./ \mathrm{ml}\right)$ for the following cancer cell types: renal, 0.07; colon, 0.04; lung, 0.12; prostate, 0.01; melanoma, 0.19 and CNS, 0.195. In addition, methionine concentration lower than $10 \mu \mathrm{M}$ is necessary for inhibition of tumor-cell growth accompanied by cell death, this level of methionine depletion can be rapidly attained at 2 units $/ \mathrm{ml}$ rMETase in vitro (Yoshioka et al., 1998). (El-Sayed et al., 2012) mentioned that the enzyme showed a remarkable activity against prostate (PC3), liver (HEPG2), and breast (MCF7) cancers, with $\mathrm{IC}_{50} 0.001 \mathrm{U} / \mathrm{mL}, 0.26 \mathrm{U} / \mathrm{ml}$, and $0.37 \mathrm{U} / \mathrm{ml}$, respectively. Toxicity of cancer cells to L-methioninase by Candida trobicalis against differed among cell lines studied by (Selim et al., 2015a); and they showed the breast cancer cell line was more sensitive $\left(\mathrm{IC}_{50} \mathrm{Of} 0.13\right.$ $\mathrm{U} / \mathrm{mL})$ than liver cancer cell line $\left(\mathrm{IC}_{50} 0.2 \mathrm{U} / \mathrm{mL}\right)$.

\section{CONCLUSION}

The bacterium Streptomyces has so far never been investigated for L-methioninase purification. The studies presented in this report show that this bacterium may be a future source for larger production of a pure thermo stable L-methioninase. Catalytic parameters of L-methioninase from Streptomyces showed new biochemical prosperities about another Lmethioninase producer. Our data observed that significantly inhibited of the different cancer cell lines and the enzyme did not display toxicity signs as shown using normal melanocytes cell line(HFB4), we can conclude that purified L-methioninase from a new source Streptomyces Sp might be a promising drug for the treatment of different cancer cells.

\section{ACKNOWLEDGMENT}

The authors wish to gratefully acknowledge the kind help of Prof. Mamdouh Moawad Ali, Biochemistry Department, Division of Genetic Engineering and Biotechnology, National Research Centre for his help in anticancer study.

\section{REFERENCES}

Anderson ME. Glutathion: an overview of biosynthesis and modulation. Chemico-Biological Interaction, 1998; 112:1-14.

Arfi K, Amarita F, Spinnler H, Bonnarme P. Catabolism of volatile sulfur compounds precursors by Brevibacterium linens and Geotrichum candidum, two microorganisms of the cheese ecosystem. Journal of Biotechnology, 2003; 105:245-253.

Bradford MM. A rapid and sensitive method for the quantitation of microgram quantities of protein utilizing the principle of protein-dye binding. Analytical Biochemistry, 1976; 72:248-254 .

Cellarier E, Durando X, Vasson MP, Farges MC, Demiden A, Maurizis JC, Madelmont JC, Chollet P. Methionine dependency and cancer treatment. Cancer Treatment Reviews, 2003; 29(6):489-499.
Dias B, Weimer B. Purification and characterization of Lmethionine $\gamma$-lyase from Brevibacterium linens BL2. Applied and Environmental microbiology, 1998; 64:3327-3331.

El-Sayed AS. Purification and characterization of a new Lmethioninase from solid cultures of Aspergillus flavipes. Journal of Microbiology, 2011; 49(1):130-140.

El-Sayed AS,. Shouman SA, Nassrat HM. Pharmacokinetics, immunogenicity and anticancer efficiency of Aspergillus flavipes Lmethioninase. Enzyme and Microbial Technology, 2012; 51(4):200-210.

Esaki N, Soda K. L-methionine $\gamma$-lyase from Pseudomonas putida and Aeromonas. Methods Enzymology, 1987; 143:459-465.

Faleev N, Troitskaya M, Paskonova M, Saporovskaya M, Belikov V. L-methionine $\gamma$-lyase in Citrobacter intermedius cells: Stereochemical requirements with respect to the thiol structure. Enzyme and Microbial Technology, 1996; 19(8):590-593.

Ferchichi M, Hemme D, Nardi M. Induction of methanethiol production by Brevibacterium linens CNRZ 918. Journal of general microbiology, 1986; 131(4):715-723.

Hori H, Takabayashi K, Orvis L, Carson DA, Nobori T. Gene cloning and characterization of Pseudomonas putida L-methionine- $\alpha$ deamino- $\gamma$-mercaptomethane-lyase. Cancer Research, 1996; 56(9):21162122 .

Ito S, Nakmura T, Eguchi Y. Purification and characterization of methioninase from Pseudomonas putida. Journal of Biochemistery, 1976; 79:1263-1272.

Kahraman H, Aytan E, Kurt AG. Production of methionine $\gamma$ lyase in recombinant Citrobacter freundii bearing the hemoglobin gene. BMB Report, 2011; 44(9):590-594.

Kokkinakis DM, Hoffman RM, Frenkel EP, Wick JB, Han Q, $\mathrm{Xu}$ M, Tan Y, Schold, SC. Synergy between methionine stress and chemotherapy in the treatment of brain tumor xenografts in athymic mice. Cancer Research, 2001; 61(10):4017- 4023.

Kreis W, Hession C. Isolation and purification of L-methioninealpha-deamino-gamma-mercaptomethane-lyase (L-methioninase) from Clostridium sporogenes. Cancer Research, 1973; 33(8):1862-1865.

Kui-Ying H, Hai-Yan H, Yan-Lai T, Feng-Geng X, Xue-Qun L, Jian-Zhong L. High-Level Expression, Purification and Large-Scale Production of L-Methionine $\gamma$-Lyase from Idiomarina as a Novel AntiLeukemic Drug. Marian Drugs, 2015; 13:5492-5507.

Laakso S, Nurmikko V. A spectroscopic assay for demethiolating activity. Anal Biochem, 1976; 72:600-605.

Laemmli UK. Cleavage of structural proteins during assembly of head of bacteriophage T4. Nature, 1970; 227:680-685.

Lockwood BC, Coombs GH. Purification and characterization of methionine $\gamma$-lyase from Trichomonas vaginalis. Biochemical Journal, 1991; 279(3):675-682.

Manukhov IV, Mamaeva DV, Rastorguev SM, Faleev NG, Morozova A, Demidkina TV, Zavilgelskyroil GB. A gene encoding Lmethionine $\gamma$-lyase is present in Enterobacteriaceae family genomes: identification and characterization of Citrobacter freundii L-methionine $\gamma$ lyase. J Bacteriol, 2005; 187(11):3889-3893.

Mosmann T. Rapid colorimetric assay for cellular growth and survival: application to proliferation and cytotoxicity assays. J Immunol Methods, 1983; 65:55-63

Nakayama T, Esaki N, Sugie K, Beresov TT, Tanaka H, Soda K. Purification of bacterial L-methionine $\gamma$-lyase. Anal Biochem, 1984; 138, (2):421-424.

Pinnamaneni R, Gangula S, Koona S, Potti R. Isolation screening and assaying of methioninase of Brevibacterium linens. Int J Sci \& Nat, 2012; 3(4):773-779. 
Schleif RF, Wensink PC. Practical methods in molecular biology. Springer-Verlag, New York, Springer- Verlag, 1981; 74.

Selim MH, Karm Eldin E, Saad MM, Mostafa EE, Shetia YH, Hassabo AA. Purification, characterization of L-methioninase from Candida tropicalis, and its application as an anticancer. BioMed Res Int J, 2015a; 173140:1-10.

Selim MH, Elshikh HH, El-Hadedy DE, Saad MM, Eliwa E, Abdelraof M. L-methioninase from some Streptomyces isolates. I: Isolation, identification of best producers and some properties of the crude enzyme produced. Journal of Genetic Engineering \& Biotechnology, 2015b; 13(2):129-137.

Sharma B, Sukhdev SS, Kanwar SS. L-methionase: A therapeutic enzyme to treat malignancies. BioMed Res Int J, 2014; 506287:1-13.

Spinnler H, Berger C, Lapadatescu C, Bonnarme P. Production of sulfur compounds by several yeasts of technological interest for cheese ripening. International Diary J, 2001; 11: 245-252.

Sundar W, Nellaiah H. Production of methioninase from Serratia marcescens isolated from soil and its anti-cancer activity against Dalton's Lymphoma Ascitic (DLA) and Ehrlich Ascitic Carcinoma (EAC) in Swiss Albino Mice. Tropical J Pharma Res, 2013; 12(5):699-704.

Tan Y,Sun X, Xu M, An Z, Tan X, Tan X, Han Q, Miljkovic DA, Yang M, Hoffaman RM. Polyethelyene glycol conjugation of recombinant methioninase for cancer therapy. Protein Expression and Purification, 1998; 12:45-52.

Tan, Y, Xu, M, and Hoffman, RM. Broad selectivity efficacy of recombinant methioninase and polyethelene glycol-modified recombinant methioninase on cancer cells in vitro. Anticancer Research, 2010; 30(4):1041-1046.
Tanaka H, Esaki N, Yamamoto T, Soda K. Purification and properties of methioninase from Pseudomonas ovalis. FEBS Letters, 1976; 66(2):307-311.

Tanaka H, Esaki N, Soda K. Bacterial L-Methionine gammalyase: Characterization and application. Progress in Clinical and Biological Res., 1983; 125:365-377.

Thong KW, Coombs GH, Sanderson BE. L-Methionine catabolism in Trichomnads. Mol. Biochem. Parasitol., 1987; 23(3):223231.

Yoshioka T, Wada T, Uchida N, Maki H, Yoshida H, Ide N, Kasai H, Hojo K, Shono K, Maekawa R, Yagi S, Hoffman RM, Sugita K. Anticancer efficiency in vivo and in vitro, synergy with 5-fluorouracil, and safety of recombinant methioninase. Cancer Research, 1998; 58(12): 2583-2587.

\section{How to cite this article:}

Selim MH, Elshikh HH, Saad MM, Eliwa E, Abdelraof M. Purification and characterization of a novel thermo stable Lmethioninase from Streptomyces sp. DMMMH4 and its evaluation for anticancer activity. J App Pharm Sci, 2016; 6 (07): 053-060. 